\title{
IDENTIFICATION OF RISKS IN THE COURSE OF MANAGING THE DEEP SEA ARCHEOLOGICAL PROJECTS USING MARINE ROBOTICS
}

\author{
Anatoly Nadtoshy \\ Department of Automatic and Electrical Equipment of Ships \\ Admiral Makarov National University of Ship Building \\ Kherson Division \\ 44 Ushakova str., Kherson, Ukraine, 73022 \\ tasman.85@mail.ru
}

\begin{abstract}
An analysis is conducted of the basic risks that occur when managing the projects of deep-sea archeological research. It is proposed to consider possible risks of such projects in the form of a general set of risks that contains subsets of the identified and unidentified risks. Based on the generalization of existing experience of conducting underwater archaeological research and with regard to the peculiarities of their execution by using TV-controlled unmanned underwater vehicles, the main risks of such operations are identified. A classification of risk factors is proposed, which takes into account weather and hydrological conditions in the area of operations, peculiarities of the underwater situation, technological and technical provision of underwater archaeological research, possible obstacles from the navigation in the explored area and errors in geographical coordinates of fulfilled work, as well as the human factor. Additionally, environmental, organizational and financial risks, which the project team is aware of, are defined as directly related to planning the projects of deep-sea archeological research. A generalized risk register is developed of the projects' deep-sea archaeological studies as theoretical foundation for designing the models of risk management and their quantitative evaluation when planning financial and temporal resources for such projects.
\end{abstract}

Keywords: underwater archaeology, project, management, identification, risk factor, risk register, robotics, unmanned underwater vehicle.

\section{Introduction}

Underwater archaeology is one of the important areas of scientific research into legacy, cultural strata, ethnic and chronological attribution. In terms of safety, among potentially possible depths for conducting archaeological research, the most promising are considered to be studies that are performed using TV-controlled unmanned underwater vehicles (UUV) and appropriate technologies [1-3].

At present, the deep-sea archeological projects belong to the class of high-technology, requiring modern technical and technological support, appropriate organizational preparation and attracting relatively large amounts of resources [4-6]. From a technical point of view, the projects should be provided with intelligent management systems, TV-controlled underwater vehicles, modern media, etc. From the point of view of the areas of conducting research, the projects are carried out in different parts of the world ocean, under various climatic conditions and at considerable depths. Taken together, these circumstances predetermine that deep-sea archeological research is accompanied by significant amount of risks, including those that may lead to canceling an archaeological project or a program.

The lack of modern models and mechanisms for risk management in the implementation of projects of deep-sea archeological research significantly affects their performance efficiency and requires solving a number of issues of theoretical and applied character.

The existence of a large number of objects of cultural heritage in the Azov-Black Sea basin of Ukraine [7, 8], their cultural and historical significance necessitates the formation and implementation of relevant projects and programs of archaeological research using UUV, which is why a scientific-applied task to create the models and mechanisms for risk management in the projects of deep-sea archaeology is actual and it has important theoretical and applied significance. 
The well-known risk management techniques provide general approaches to reducing their impact on the success of the project. In this case, the basis of methodology for risk management is the stages of their identification, qualitative and quantitative evaluation $[9,10]$.

An analysis of approaches and solutions for risk management in the projects of deep-sea research that we conducted revealed that the currently existing studies consider particular projects and does not provide for the creation of complete "check-list" of the identified risks [11-14]. Thus, paper [11] identified risks associated with the operation of UUV under severe meteorological conditions, which requires increasing their energy capacity, management and communication quality, design of sensor systems of a new generation. Specific risks related to the operation of marine platforms and their manintenance are examined in [12]. The problematic issues include technological aspects of using UUV when carrying out research in deeper and hard-to-access areas of the ocean, the uncertainty linked to the ground spatial variability, etc. Articles [12, 13] determined the risk of collision between UUV and the elements of pipelines, described the consequences of collisions and the measures for their reduction. The issue of connection of technical and operating risks with the processes of developing and deploying naval robotics is dealt with in paper [14]. The authors highlighted the risks associated with the software performance, navigation systems, and project team. The main problems include the risks associated with the workability of power equipment. When considering the operational stages of a project, emphasized are the risks associated with weather and hydrological conditions of research, the risks of UUV collision when discharging from the carrier ship, the risks of losing UUV and subsequent search for it, etc. The existing risks of an institutional nature are stressed. The paper proposes a "spiral model" of reducing technical risks, which implies the iterative approach to the creation of UUV.

The measures to reduce the operational risks are proposed through project budget planning in the context of thorough preparation of the operators. Article [15] presented examples of the risk management processes for autonomous underwater vehicles that working under conditions of ice environment, which are based on the cooperation between the customer and technical team of the project.

The aim of this work is to identify the risks that occur in the projects of deep-sea archeological research using TV-controlled unmanned underwater vehicles as the theoretical basis for their further consideration in the projects of deep-sea archaeology.

\section{Materials and methods of research}

The identification of risks is the basis for the development of models for risk management in the projects of deep-sea archeological research. The detection of risks creates conditions for designing the processes of project management, including budget planning, timing and quality of the project implementation. The risks defined make it possible to determine the required reserves of financial resources and deadlines

$$
\begin{gathered}
\Delta \mathrm{C}=\sum_{\mathrm{i}=1}^{\mathrm{n}} \mathrm{C}_{\mathrm{i}}\left(\mathrm{r}_{\mathrm{i}}\right)+\sum_{\mathrm{j}=1}^{\mathrm{k}} \mathrm{C}_{\mathrm{j}}\left(\mathrm{r}_{\mathrm{j}}\right), \\
\Delta \mathrm{T}=\sum_{\mathrm{i}=1}^{\mathrm{n}} \mathrm{T}_{\mathrm{i}}\left(\mathrm{r}_{\mathrm{i}}\right)+\sum_{\mathrm{j}=1}^{\mathrm{k}} \mathrm{T}_{\mathrm{j}}\left(\mathrm{r}_{\mathrm{j}}\right),
\end{gathered}
$$

where $\Delta \mathrm{C}$ is the required reserve of financial resources to cover possible risks; $\sum_{\mathrm{i}=1}^{\mathrm{n}} \mathrm{C}_{\mathrm{i}}$ is the re quired reserve of financial resources to cover identified potential risks; $\sum_{j=1}^{k} C_{k}$ is the required reserve of financial resources to cover unidentified risks; $\Delta \mathrm{T}$ is the required reserve of terms for the execution of work to cover possible risks; $\sum_{i=1}^{n} T_{i}$ is the required reserve of terms for the execution 
of work to cover potential risks; $\sum_{\mathrm{j} 1}$ is the required reserve of terms for the execution of work to cover unidentified risks; $r_{i}$ is the $i$-th identified risk; $r_{j}$ is the $j$-th unidentified risk.

In this case, there are dependences:

$$
\begin{gathered}
\mathrm{R}_{\mathrm{N}}=\left\{\begin{array}{lllll}
\mathrm{r}_{1}, & \ldots & \mathrm{r}_{\mathrm{i}}, & \ldots & \mathrm{r}_{\mathrm{n}}
\end{array}\right\}, \\
\mathrm{R}_{\mathrm{K}}=\left\{\begin{array}{lllll}
\mathrm{r}_{1}, & \ldots & \mathrm{r}_{\mathrm{i}}, & \ldots & \mathrm{r}_{\mathrm{k}}
\end{array}\right\}, \\
\mathrm{R}=\mathrm{R}_{\mathrm{N}} \cup \mathrm{R}_{\mathrm{K}},
\end{gathered}
$$

where $R_{N}$ and $R_{K}$ are the subsets of identified and unidentified risks, respectively, according to dependences (1) and (2); $\mathrm{R}$ is the general set of risks that occur in the organization and implementation of underwater archaeological research.

It is obvious that the main task of project managers of such projects is reducing subset $R_{K}$ to minimum:

$$
\mathrm{R}_{\mathrm{K}} \rightarrow \min
$$

and

$$
\mathrm{R}_{\mathrm{N}} \rightarrow \mathrm{R}
$$

An analysis of approaches and solutions for risk management in the projects of deep-sea research, which we conducted, allowed us, based on the method of expert analysis, and taking into account the peculiarities of performing archaeological operations, to identify basic risks $\mathrm{R}_{\mathrm{N}}$, which occur in the projects of deep-sea archeological research (Fig. 1).

The basic risk factors that are conditionally divided into relevant groups include the following subsets of risk factors: "Coordinates of research $\mathrm{R}_{C}$ ", "Weather conditions $\mathrm{R}_{\mathrm{M}}$ ", "Hydrological conditions $\mathrm{R}_{\mathrm{G}}$ ", "Underwater situation $\mathrm{R}_{\mathrm{U}}$ ", "Technological provision $\mathrm{R}_{\mathrm{T}}$ ", "Technical support $\mathrm{R}_{\mathrm{Z}}$ ", "Team $\mathrm{R}_{\mathrm{L}}$ ”, as well as "Check-list $\mathrm{R}_{\mathrm{Ch}}$ ".

Thus, general set of risks $\mathrm{R}(5)$ can be represented as dependence on the specified subsets:

$$
\mathrm{R}=\left\{\mathrm{R}_{\mathrm{C}} ; \mathrm{R}_{\mathrm{M}} ; \mathrm{R}_{\mathrm{G}} ; \mathrm{R}_{\mathrm{U}} ; \mathrm{R}_{\mathrm{T}} ; \mathrm{R}_{\mathrm{Z}} ; \mathrm{R}_{\mathrm{L}} ; \mathrm{R}_{\mathrm{Ch}}\right\}
$$

In turn, these risk factors include the following basic risks:

- the risk of existence of pipelines, associated with the uncertainty of the presence of pipelines in the area of research;

- the risk of existence of electric cables, associated with the uncertainty of the presence of electric cables and optical fiber communication elements;

- the risk of existence of explosives, associated with the uncertainty of the presence of explosives in the area of research;

- the risk of complexity of the bottom surface, associated with the features of the bottom surface in the area of research;

- the risk, associated with existence in the area of research of objects of chemical and radioactive hazards;

- the risks, associated with stormy, windy, temperature and ice conditions in the area of research;

- the risks, associated with anomalous conditions of hydrology, currents, silting, transparency and water salinity in the area of research;

- the risks of the choice of technology of conducting deep-sea archeological research;

- the risks, associated with the choice of equipment to conduct deep-sea archeological research; 
- the risks, associated with the choice of UUV carrier ship whose specifications may not fully meet the requirements of the underwater archeological expedition;

- the risks, associated with the choice of software that involved in planning and managing marine archaeological expedition;

- the risks, associated with the choice of geographic coordinates of research, which makes it difficult or impossible to perform operations (active shipping in the area of performed underwater archaeological research, mistakes in determining the location of discharge of carrier-ship and UUV dive);

- the risks, associated with management errors;

- the risks, associated with disease in the team;

- the risks, associated with malfunctioning of the equipment installed at UUV;

- the risks, associated with the breaking of cable-rope of UUV;

- the risks, associated with the loss of UUV.

Risk-factor "Check-list" contains the risks known to the project team, associated with the projects of deep-sea archeological research, including environmental, organizational, financial, etc.

We compiled a risk register based on the defined risks, which is represented in Table $\mathbf{1 .}$

The register of risks, which is represented in Table 1, as well as dependences (1)-(6) enable us to perform qualitative assessment of risks of the projects in deep-sea archeological research, and may serve a theoretical basis for the development of models for risk management and their quantitative evaluation when planning reserves of financial and time resources to such projects.

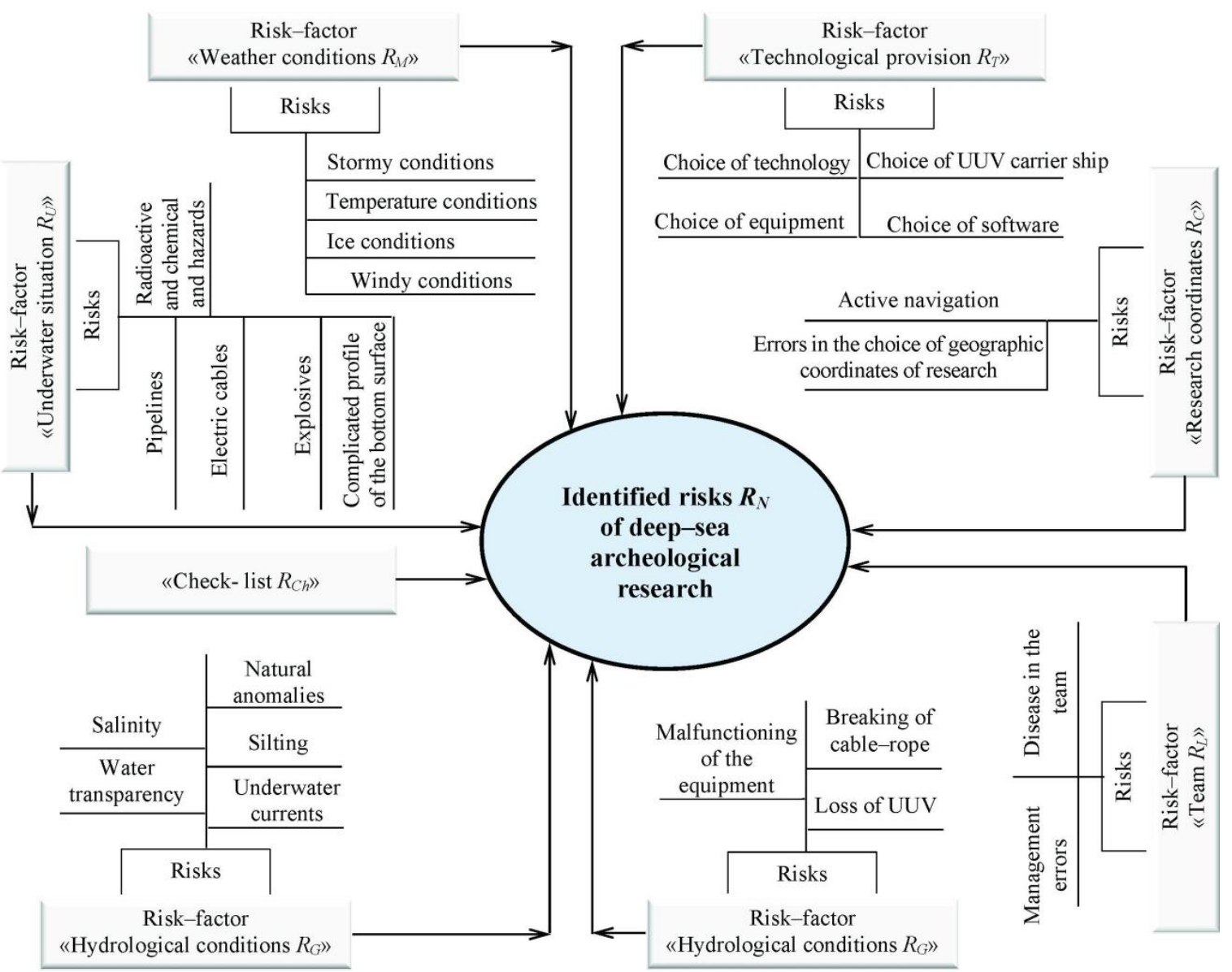

Fig. 1. Identified basic risks $R_{N}$ of the projects in deep-sea archeological research using TV-controlled UUV 
Table 1

Risk register of the projects of deep-sea archeological research

\begin{tabular}{c}
\hline Risk name \\
\hline Risk of existence of pipelines \\
Risk of existence of electric cables \\
Risk of existence of explosives \\
Risk of complexity of \\
the bottom surface \\
Risk associated with existence of \\
objects of chemical and \\
radioactive hazards \\
Risks associated with stormy, \\
windy, temperature and \\
ice conditions
\end{tabular}

Risks associated with anomalous conditions of hydrology, currents, silting, transparency and water salinity

Risks of the choice of technology for conducting deep-sea archeological research

Risks associated with the choice of equipment

Risks associated with the choice of UUV carrier ship

Risks associated with the choice of software

Risks associated with the choice of geographic coordinates of research

Risks associated with management errors

Risks associated with a disease in the team

Risks associated with malfunctioning of the equipment

Risks associated with the breaking of cable-rope

Risks associated with the loss of UUV
Reason of occurrence

$$
2
$$

Consequences 3

Lack of information resources, Project dismissal, increase in errors in planning budget and prolongation of

the project operations project terms

Lack of information resources, Project dismissal, increase in errors in planning

the project operations budget and prolongation of project terms

Lack of information resources, Project dismissal, increase in errors in planning the operations budget and prolongation of project terms

Lack of information resources, errors in planning the operations

Lack of information resources, errors in planning the operations

Lack of information resources, errors in planning

the operations, lack of practical experience

Lack of information resources, Project dismissal, increase in errors in planning the operations

Errors in planning the operations

Errors in planning the operations

Errors in planning the operations

Errors in planning the operations, lack of practical experience

Errors in planning the operations

Insufficient competency of the project team

State of individual health, work and safety conditions

Errors in planning, in selecting the equipment, weather and hydrological conditions of research Errors in planning, in selecting the equipment, weather and hydrological conditions of research Errors in planning, in selecting the equipment, weather and hydrological conditions of research
Increase in budget and prolongation of project terms

Project dismissal

Project dismissal, increase in budget and prolongation of project terms, loss of artifact budget and prolongation of project terms, loss of artifact

Increase in budget and prolongation of project terms, loss of artifact

Increase in budget and prolongation of project terms, loss of artifact

Increase in budget and prolongation of project terms

Increase in budget and prolongation of project terms

Project dismissal, increase in budget and prolongation of project terms

Increase in budget and prolongation of project terms, loss of artifact

Increase in budget and prolongation of project terms

Project dismissal, increase in budget and prolongation of project terms, loss of artifact

Project dismissal, increase in budget and prolongation of project terms, loss of artifact

Project dismissal, increase in budget and prolongation of project terms
Reaction measures 4

Change in

the technology of research

Change in

the technology of research

Change in

the technology of research

Change in the technology

of research, replacement of equipment

Correction of operations terms

Change in the technology of research, replacement of equipment, correction of operations terms

Change in the technology of research, replacement of equipment, correction of operations terms

Replacement of equipment, correction of operations terms

Replacement of equipment, correction of operations terms

New software delivery

Improvement in the processes of planning the operations

Team members certification, additional training

Health-improving measures, combining skills, back-up

Improvement in the processes of planning and fulfilling the operations, maintenance

Improvement in the processes of planning and fulfilling the operations, maintenance work, certification, back-up Improvement in the processes of planning and fulfilling the operations, maintenance work, certification, back-up 


\section{Conclusions}

1. Basic groups of risk factors are defined in the projects of deep-sea archeological studies, which are carried out using TV-controlled unmanned underwater vehicles and linked to the location (coordinates) of research operations, weather conditions, underwater situation in the area of research, hydrological conditions, technological and technical support, as well as the project team. The identified risks will complement the existing "Check-lists" of risks in the projects of deep-sea archeological research.

2. The risk register we compiled makes it possible to perform qualitative and quantitative risk evaluation in the projects of deep archaeological research, to carry out their ranking by the reasons of their occurrence, consequences and measures of response.

3. The results of the identification of risks that we received is a theoretical basis for the construction of adequate mathematical models of risk management in the projects of deep-sea archeological research that involves robotics, which are planned to be implemented in marine areas under complicated navigation and climatic conditions.

4. A positive result of the study is the detection of a general set of risks that occur when organizing and performing the deep-sea underwater archaeological research, as well as the identification of their basic subset. It creates theoretical basis for their formal descriptions and consideration when planning the projects of underwater operations of this type by domestic and foreign organizations.

5. Unresolved part of the problem is the lack of a formalized description of the subset of unidentified risks of such projects when planning their financial and temporal reserves. The solution to this problem has to be found in the course of further research.

\section{References}

[1] Gould, R. A., Green, J. (1991). Maritime Archaeology: A Technical Handbook. Journal of Field Archaeology, 18 (2), 246-249. doi: 10.2307/530269

[2] Blintsov, V. S., Voronov, S. O. (2010). Bazovi tekhnolohii zastosuvannia pidvodnykh aparativ-robotiv dlia zadach morskoi arkheolohii. Innovatsii v sudnobuduvanni ta okeanotekhnitsi. Materialy mizhnarodnoi naukovo-tekhnichnoi konferentsii. Mykolaiv: NUK, 389-391.

[3] Blintsov, V. S., Voronov, S. O., Nadtochii, A. V. (2012). Aktualni zadachi vdoskonalennia zakonodavchoi ta normatyvnoi bazy yak skladovi proektiv zberezhennia ta muzeiefikatsii pidvodnoi kulturnoi spadshchyny Ukrainy. Zbirnyk naukovykh prats NUK, 2 (443), 109-104.

[4] Guidance for developing Maritime Unmanned Systems (MUS) capability. (09.07.2012). Available at: https://publicintelligence.net/cjoscoe-mus/

[5] Green, J. (2009). Underwater Archaeology: the NAS Guide to Principles and Practice. International Journal of Nautical Archaeology, 38 (1), 191-193. doi: 10.1111/j.1095-9270.2008.220_13.x

[6] Dizon, E., Egger, B., Elkin, D., Erreguerena, P. L., Grenier, R., Gribble, J., Guérin U.; In: Maarleveld, T. J., Guérin, U., Egger, B. (2013). Manual for Activities directed at Underwater Cultural Heritage. Paris: United Nations Educational, 351.

[7] Nazarov, V. V. (2003). Gidroarheologicheskaia karta Chernomorskoi akvatorii Ukrainy (pamiatniki antichnoi i srednevekovoi epoh). Kyiv: Ctilos, 160.

[8] Voronov, S. O. (2008). Entsyklopediia morskykh katastrof Ukrainy: (zatonuli pamiatky antych., serednovich. i novit. istorii: zalyshky mist i poselen, viisk. korabli, tsyvil. sudna, avia- ta bronetekhnika). Kyiv: Bohdana, 892.

[9] Lee, E. (2012). "Everything We Know Informs Everything We Do": A Vision for Historic Environment Sector Knowledge and Information Management. The Historic Environment: Policy \& Practice, 3 (1), 28-41. doi: 10.1179/1756750512z.0000000006

[10] Project Management Institute. (2013). Rukovodstvo k Svodu znanyi po upravlenyiu proektamy (Rukovodstvo PMBOK). Project Management Institute, 176. Available at: http://static2.ozone.ru/multimedia/ book_file/1012041519.pdf

[11] Unmanned Systems Integrated Roadmap FY2013-2038 (2013). Available at: http://archive.defense.gov/pubs/DOD-USRM-2013.pdf

[12] WS Atkins Consultants Ltd. (2004). Risk implications in site characterisation and analysis for offshore engineering and design. HSE BOOKS, 116. Available at: http://www.hse.gov.uk/research/rrpdf/rr286.pdf

[13] Hirvonen, J., Riuttamaki, T., Mollestad, K. (2014). Inspection of risers with submarine robotics; technology, risks and regulations. Lisboa: Instituto Superior Technico, 24.

[14] Manley, J. E. (2007). The Role of Risk in AUV Development and Deployment. OCEANS 2007 Europe. doi: 10.1109/oceanse.2007.4302219

[15] Griffiths, G., Brito, M. P. (2011). Risk Management for Autonomous Underwater Vehicles Operating Under Ice. OTC Arctic Technology Conference, 8. doi: 10.4043/22162-ms 